\title{
Use of Melatonin in the In Vitro Production of Bovine Embryos
}

\author{
Uso da Melatonina na Produção In Vitro de Embriões Bovinos
}

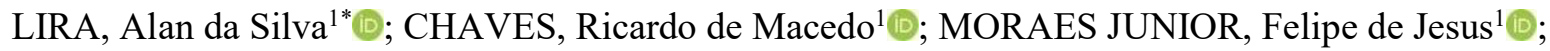 COSTA JUNIOR, Sergio Henrique ${ }^{1}{ }^{0}$; AMARAL, Brenda Karine Lima do ${ }^{1}{ }^{\circ}$; TROVÃO, Hallef Mithchel Pereira ${ }^{1}$ O

\author{
${ }^{1}$ Universidade Estadual do Maranhão, Departamento de Ciências Agrárias, São Luís, Maranhão, Brasil \\ *Mail for correspondence: alanslira_1414@hotmail.com
}

\begin{abstract}
We aimed to assess the effects of melatonin in the in vitro production of bovine embryos. Our experiment was conducted at the Laboratório de Reprodução Animal of the Universidade Estadual do Maranhão. The cumulus-oocyte complexes (COCs) were distributed among treatments at concentrations of $0,10^{-1}, 10^{-3}$ and $10^{-5} \mu \mathrm{Mol} / \mathrm{L}$ melatonin. Our experiment was further divided into two: the first was to assess the effect of different concentrations of melatonin (treatments) on the maturation rate of COCs, and the second was to assess the effects of melatonin treatments on the in vitro production of bovine embryos. The results from the first experiment demonstrated no significant difference between the in vitro maturation rate of the cultivated COCs in treatments with melatonin. In the second experiment, however, melatonin treatments yielded statistically higher cleavage, morula and blastocyst rates in the $10^{-5} \mu \mathrm{M}$ group $(52.9 \%, 52.9 \%$, and $35.3 \%$, respectively), and lower rates in the $10^{-1} \mu \mathrm{M}$ group $(19.5 \%, 19.5 \%$ and $7.8 \%$, respectively), compared to the others. The control group (no melatonin) and the $10^{-3} \mu \mathrm{M}$ group showed similar results. We concluded that supplementation of melatonin in the in vitro maturation medium resulted in no improvement in the oocyte maturation rate, but in the in vitro production of embryos at different concentrations, the $10^{-5} \mu \mathrm{M}$ group displayed better results, but with no improvement in the variables $(\mathrm{P}<0.05)$.
\end{abstract}

Keywords: COC, Melatonin, IVP, Follicular Aspiration.

\section{RESUMO}

Objetivou-se avaliar os efeitos da melatonina na produção in vitro de embriões bovinos. $\mathrm{O}$ experimento foi conduzido no Laboratório de Reprodução Animal da Universidade Estadual do Maranhão. Os complexos cumulus-oócitos (CCOs) foram distribuídos entre os tratamentos $0,10-1,10-3$ e $10-5 \mu \mathrm{mol} / \mathrm{L}$ de melatonina. A avaliação foi dividida em dois experimentos, onde o primeiro avaliou o efeito dessas diferentes concentrações de melatonina (tratamentos) sobre a taxa de maturação dos CCOs e o segundo, o efeito desses tratamentos com melatonina sobre a produção in vitro de embriões bovinos. Os resultados no primeiro experimento demonstraram não haver diferença significativa na taxa de maturação in vitro dos CCOs cultivados no tratamento com melatonina. No entanto, o tratamento com melatonina no segundo experimento, as taxas de clivagens, mórulas e blastocistos, o grupo $10-5 \mu \mathrm{M}$ foi estatisticamente superior $(52,9 \%$, $52,9 \%$ e $35,3 \%$, respectivamente) e o grupo 10 $1 \mu \mathrm{M}$ inferior $(19,5 \%, 19,5 \%$ e $7,8 \%$, respectivamente) aos outros grupos. O grupo controle (sem melatonina) e o grupo 10-3 $\mu \mathrm{M}$ obtiveram resultados semelhantes. Concluiu-se que a suplementação da melatonina no meio de maturação in vitro não evidenciou melhoras na taxa de maturação dos oócitos, porém na produção in vitro de embriões em diferentes concentrações, o grupo 10-5 $\mu \mathrm{M}$ apresentou melhores resultados mesmo não havendo melhorias nas variáveis $(\mathrm{P}<0,05)$.

Palavras-chave: CCOS, Melatonina, PIV, Aspiração folicular 


\section{INTRODUCTION}

Biotechnologies are a set of techniques implemented to manipulate organisms and/or their components, associated with molecular biology, cloning and genetic engineering (Wetherington, 2010).

In vitro production (IVP) is a biotechnology that consists in recovering immature oocytes from ovarian follicles, thus allowing for the intensification of use of animals with high genetic value (Merton et al., 2003). The year 2017 is a historic landmark in the production of bovine embryos. For the first time in the records of the International Embryo Technology Society (IETS), the total number of IVP embryos surpassed those produced in vivo (992,289 versus 406,287, respectively) (Viana, 2018).

According to Thompson et al. (2007), several IVP methods have been employed to produce embryos from immature oocytes. Bovine IVP reaches average development rates of 20 to $40 \%$ until the blastocyte stage.

In the context of reproductive biotechnology, the quality and integrity of cumulus-oocyte complexes (COCs) influence the success of in vitro cultivation. Thus, oxidative stress is a relevant factor that impairs in vitro development of COCs and the fertilization and in vitro culture of the embryo. Melatonin is a product of the pineal gland, acting as a potent antioxidant and eliminating reactive oxygen species (ROS), altogether avoiding oxidative stress during fetal development. It also plays other roles, such as modulating the ovarian function in mammals (Tsantarliotou et al., 2007). In this way, it can effectively alleviate aging in in vitro-produced oocytes provoked by oxidative stress, thus delaying the beginning of apoptosis and avoiding cell fragmentation (Lord et al., 2013).
Some effects of melatonin are mediated through specific membrane receptors, but many seem to be based on its potential as a direct scavenger of free radicals (Tamura et al., 2012). The presence of heightened levels of melatonin in the pre-ovulatory follicular fluid points to its possible role in the acquisition of oocyte competence during the process of maturation, fertilization and fetal development (Tsantarliotou et al., 2007).

Our research aimed at assessing the effects of melatonin in the production of in vitro bovine embryos considering the morphological aspects of the maturation of COCs and fetal development.

\section{MATERIALS AND METHODS}

Our experiment was conducted at the Laboratório de Reprodução Animal (LABRA) of the Universidade Estadual do Maranhão (UEMA). Ovaries were collected at the Municipal DA Vital slaughterhouse, located at BR $-135, \mathrm{~km} 03$, in São Luís, Maranhão, Brazil.

Viable COCs were distributed between treatments of $0,10^{-1}, 10^{-3}$ and $10^{-5} \mu \mathrm{M}$ melatonin during in vitro maturation in all experiments. Our experiment was then divided in two phases: the first assessed the effects of distinct melatonin concentrations (treatments) on the maturation rate of COCs and the second assessed the effects of melatonin treatments on the in vitro production of bovine embryos. We used a total of $100 \mathrm{COCs}$ per treatment, during both phases.

The following methods and proceedings herein described were approved by the Ethics and Animal Experimenting Committee (CEEA) of the Veterinary Medicine major at UEMA, agreeing with protocol $n^{\circ} 14 / 2016$, approved on August $5^{\text {th }} 2016$, to conduct the research by observing the standards of Animal Welfare 
on CRMV resolution $\mathrm{N}^{\mathrm{o}} 1000 / 2012$ and Brazilian Law 11.794/2008.

Ovaries were transported to the laboratory in a thermal vessel with $0.9 \%$ physiological solution containing $10 \%$ gentamicin at a temperature of $37^{\circ} \mathrm{C}$. At the laboratory, ovaries were washed with $0.9 \%$ physiological solution at $37{ }^{\circ} \mathrm{C}$, and COCs measuring between 2 and $6 \mathrm{~mm}$ were recovered by follicular aspiration, using 25 x $8 \mathrm{~mm}$ sterile needles $(21 \mathrm{~g})$ coupled to a $10 \mathrm{~mL}$ syringe. The follicular liquid obtained was then stored in $15 \mathrm{~mL}$ Falcon tubes in a water bath at $37^{\circ} \mathrm{C}$ for $20 \mathrm{~min}$ for sedimentation. The aspired follicular contents were deposited on 100 x $20 \mathrm{~mm}$ Petri dishes for further research under a stereomicroscope. The selected COCs were transferred to $30 \times 10 \mathrm{~mm}$ Petri dishes containing maintenance medium (TQC Holding Plus) and classified according to their morphological quality as Grade I, II, III or IV (Leidfried \& First 1979). Only COCs of Grades I and II were selected for maturation.

COCs were washed three times in drops containing in vitro maturation (IVM) medium in $100 \times 20 \mathrm{~mm}$ Petri dishes, then transferred to micro drops containing 100 $\mu \mathrm{L}$ IVM medium in $60 \times 15 \mathrm{~mm}$ Petri dishes, which were numbered and contained eight IVM drops covered in mineral oil (Sigma-Aldrich, USA) at a temperature of $38.8{ }^{\circ} \mathrm{C}$, in a gaseous atmosphere of $5 \% \mathrm{CO}_{2}$ for $24 \mathrm{~h}$. This in vitro maturation protocol for COCs was used during the first and second phases. This treatment was applied to all samples.

Melatonin was diluted in DMSO (dimethyl sulfoxide) at a concentration of $1 \mathrm{mg} / \mathrm{mL}$, then stored at $-20{ }^{\circ} \mathrm{C}$ in $1 \mathrm{~mL}$ cryogenic tubes. During the first phase, melatonin was added to a micro drop containing maturation medium, following the treatment concentrations. After $24 \mathrm{~h}$, COCs were kept for $10 \mathrm{~min}$ in a
NUNCLON® plate containing $400 \mu \mathrm{L}$ denudation medium ( $1 \mathrm{~mL}$ TCQ Holding + $10 \mathrm{mg} / \mathrm{mL}$ hyaluronidase); then, COCs underwent mechanical agitation to remove cumulus cells, evaluated under a stereoscope, for extrusion of the first polar corpuscle.

In the second phase, COCs were matured and, after $24 \mathrm{~h}$ of maturation, were washed three times in $900 \mu \mathrm{L}$ fertilization medium supplemented with $20 \mu \mathrm{L}$ heparin and 40 $\mu \mathrm{L}$ PHE (penicillamine, hypotaurine and epinephrine) solution.

Semen was provided from a single Gir bull and batch. It was unfrozen in water at $37^{\circ} \mathrm{C}$ for $30 \mathrm{~s}$, then deposited in a $1.5 \mathrm{~mL}$ Eppendorf over a $45 \%$ and $90 \%$ Percoll gradient submitted to a centrifuging force of $251 \mathrm{~g}$ for $10 \mathrm{~min}$. A $10 \mu \mathrm{L}$ volume was removed to assess motility and initial vigor. After centrifuging, spermatozoids at the bottom of the Eppendorf were aspirated and put in $1 \mathrm{~mL}$ of in vitro fertilization medium, then resubmitted to a $251 \mathrm{~g}$ centrifugation for $5 \mathrm{~min}$. After the second centrifugation, the excess in vitro fertilization (IVF) medium was removed. A $10 \mu \mathrm{L}$ sample was used for a final evaluation of sperm motility and vigor. Then, $5.0 \mu \mathrm{L}$ of the suspension was removed and added to $95 \mu \mathrm{L}$ water for determination of sperm concentration by sperm cell count in a Neubauer chamber. Final sperm concentration was adjusted to 25 million live spermatozoids $/ \mathrm{mL}$. Afterwards, COCs and spermatozoids were co-incubated at $38.8^{\circ} \mathrm{C}$ for 18 to $22 \mathrm{~h}$, under $20 \% \mathrm{O}_{2} / 5 \% \mathrm{CO}_{2}$ saturated humidity air.

After in vitro fertilization, the presumed zygotes were washed three times in drops of synthetic oviduct fluid, deposited in 100 $\mu \mathrm{L}$ drops and covered in mineral oil. Cleavage rate was assessed three days after the beginning of fecundation (Day 0). Embryo development (morula rate, initial blastocyst, complete blastocyst and 
expanded blastocyst) was assessed at the fifth and seventh days (Days 5 and 7) following the beginning of fecundation. The entire experiment design was random with four treatments $\left(0,10^{-1}, 10^{-3}\right.$ and $10^{-5}$ $\mu \mathrm{M}$ melatonin) with 100 repetitions (number of COCs). At the first phase, we assessed the effect of melatonin on oocyte maturation; at the second phase we assessed the effect of melatonin on the in vitro production. The variables studied during the first phase (maturation rate) and second phase (cleavage rate, total blastocyst rate and proportion of viable embryos,

\section{RESULTS AND DISCUSSION}

\section{Experiment 1}

We used 453 viable COCs in our experiment, and then distributed 116, 101, proportion per development stage and embryo quality) were submitted to a normality test. Normal data and data normalized under mathematical transformations (logarithmic, arcsine) were then submitted to analysis of variance (ANOVA) or to the Student-NewmanKeuls (SNK) parametric test for comparison of means, at a probability of 5\%. Qualitative data were compared using the $\chi 2$ test, considering $\mathrm{P}<0.05$. Our analyses were conducted using software Statistical Analysis System (SAS Institute Inc, 1997).

113 and 126 COCs to groups $0,10^{-1}, 10^{-3}$ and $10^{-5} \mu \mathrm{M}$ melatonin, respectively, as shown in Table 1.

Table 1. Oocyte maturation rate of oocytes cultivated in vitro in medium supplemented with different melatonin concentrations and total COCs used per treatment. Numbers followed by distinct uppercase letters differ by the $\chi^{2}$ test $(\mathrm{P}<0.05)$.

\begin{tabular}{lllll} 
Maturation & $\mathbf{0}$ & $\mathbf{1 0}^{-\mathbf{5}}$ & $\mathbf{1 0}^{-\mathbf{3}}$ & $\mathbf{1 0}^{-\mathbf{1}}$ \\
\cline { 2 - 5 } Rate $(\boldsymbol{\mu M})$ & $49.14 \%$ & $29.27 \%$ & $45.13 \%$ & $17.82 \%$ \\
& $(57 / 116)^{\mathrm{A}}$ & $(36 / 126)^{\mathrm{B}}$ & $(51 / 113)^{\mathrm{A}}$ & $(18 / 101)^{\mathrm{B}}$
\end{tabular}

Regarding the maturation rate of in vitrocultivated COCs, we observed that there was a significant difference at $0 \mu \mathrm{M}$ melatonin (49.14\%) in comparison to those at concentrations of $10^{-1} \mu \mathrm{M}(17.82 \%)$ and $10^{-5} \mu \mathrm{M}(29.27 \%)$. However, there was no significant difference when compared to a concentration $10^{-3} \mu \mathrm{M}(45.13 \%)$.

These results corroborate those of Adona et al. (2008), where an addition of $100 \mu \mathrm{M}$ melatonin in an in vitro maturation medium did not interfere with the maturation rate and on the fetal development stages. However, our results differ from studies in which $1 \mu \mathrm{M}$ and $100 \mu \mathrm{M}$ melatonin concentrations increased fetal development in bovines (Tan et al., 1993).

Manjunatha et al. (2009), using 20 and 50 $\mu \mathrm{M}$ melatonin in maturation medium of buffalo oocytes, obtained higher oocyte maturation percentages $(90.3 \%$ and $88.8 \%$, respectively), reporting a stimulatory effect of melatonin on in vitro maturation, thus differing from our present study.

The ability to undergo germinal vesicle breakdown and progress to metaphase I is acquired at the beginning of the growth phase, but the ability to progress to metaphase II is acquired later (Motlik; Fulk, 1986; Thibault et al., 1987). 
Studies have demonstrated that some factors can improve oocyte competence, thus significantly increasing the number of blastocysts produced in vitro (Sirard et al., 1998). Although we know the influence of

\section{Experiment 2}

Rates of cleavage, morula and blastocysts from our study groups are represented in Table 2. We observed that, compared to the control group, the rate of cleavage, morulae and blastocyst of the $10^{-5} \mu \mathrm{M}$ treatment culture media and conditions, the oocyte's own original constituents are responsible for controlling the ability to respond to the most appropriate culture conditions (Sirard, 2001).

group differed in a statistically positive way $(\mathrm{P}<0.05)$ in comparison to other groups, while the $10^{-1} \mu \mathrm{M}$ treatment group differed negatively $(\mathrm{P}<0.05)$ in comparison to the other groups. However, no dose was effective in improving these variables.

Table 2. Rate of cleavage, morula and blastocysts produced in vitro from COCs originated from post-mortem ovaries collected in a slaughterhouse for embryo IVP, submitted or not to different melatonin treatments. Numbers followed by distinct lowercase letters differ by the $\chi 2$ test $(\mathrm{P}<0.05)$.

\begin{tabular}{|c|c|c|c|c|}
\hline & $\begin{array}{l}\text { Number } \\
\text { COCs }\end{array}$ & Cleavage rate & Morula rate & Blastocyst rate \\
\hline Control & 83 & $32\left(38.6^{\mathrm{a} \%} \%\right)$ & $30\left(36.1^{\mathrm{ab}} \%\right)$ & $15\left(18.1^{\mathrm{b}} \%\right)$ \\
\hline $10^{-5} \mu \mathrm{M}$ & 51 & $27\left(52.9^{\mathrm{a} o} \%\right)$ & $27\left(52.9^{\mathrm{a}} \%\right)$ & $18\left(35.3^{\mathrm{a} \%} \%\right)$ \\
\hline $10^{-3} \mu \mathrm{M}$ & 88 & $36\left(40.9^{\mathrm{a} \%} \%\right)$ & $31\left(35.2^{\mathrm{bo}} \%\right)$ & $8\left(9.1^{\mathrm{b} \%} \%\right)$ \\
\hline $10^{-1} \mu \mathrm{M}$ & 77 & $15\left(19.5^{\mathrm{b} \%} \%\right)$ & $15\left(19.5^{\mathrm{c}} \%\right)$ & $6\left(7.8^{\mathrm{b} \%} \%\right)$ \\
\hline
\end{tabular}

Compared to melatonin treatments, groups with smaller doses, $10^{-5} \mu \mathrm{M}$ and $10^{-3} \mu \mathrm{M}$, presented an increased cleavage rate compared to groups submitted to higher melatonin doses and to the control group. This reinforces the literature, in which it is observed that melatonin supplementation in an embryo culture medium at a concentration of $10^{-9} \mu \mathrm{M}$ has a positive effect on the cleavage rate and on the number of swine blastocyst cells (Rodriguez-Osório et al., 2007).

Bovine IVP reaches average rates of 20 to $40 \%$ blastocyst rates (Thompson et al., 2007). This highlights the $10^{-5} \mu \mathrm{M}$ treatment group as a good option, as the blastocyst rate in this group reached 35.3\% and guaranteed better results than the control group, even if did not improve the variables.
Although the melatonin dose in this experiment was used before the in vitro maturation, according to Papis et al. (2007), the melatonin dose was used during in vitro culture of bovine embryos and was questionable regarding the doses of $10^{-4}$ to $10^{-7} \mu \mathrm{M}$ melatonin in the medium.

These previous results agree with studies in which melatonin concentrations of $10^{-4}$ to $10^{-9} \mu \mathrm{M}$ increased murine and bovine fetal development (Tan et al., 1993; Siu et al., 2006).

Fetal development rates based on the stop stage of the in vitro development are represented in Table 3. Considering the proportion of morulas, the $10^{-3} \mu \mathrm{M}$ group was superior to the rate obtained by the $10^{-}$ ${ }^{5} \mu \mathrm{M}$ group and similar to the control and $10^{-1} \mu \mathrm{M}$ groups $(\mathrm{P}<0.05)$. Control, $10^{-1}$ 
$\mu \mathrm{M}$ and $10^{-5} \mu \mathrm{M}$ groups were similar $(\mathrm{P}<$ $0.05)$.

Table 3. Fetal development rate based on the stop stage of in vitro development from COCs originated from post-mortem ovaries collected from slaughterhouses for embryo IVP, submitted or not to different melatonin treatments, evaluated on Days 5 and 7 after Day 0. Numbers followed by distinct lowercase letters differ by the $\chi 2$ test $(\mathrm{P}<0.05)$.

\begin{tabular}{llllll}
\hline & Morula & $\begin{array}{l}\text { Initial } \\
\text { blastocyst }\end{array}$ & Blastocyst & $\begin{array}{l}\text { Expanded } \\
\text { blastocyst }\end{array}$ & TOTAL \\
\hline Control & $15(50.0 \%)^{\mathrm{ab}}$ & $7(23.3 \%)^{\mathrm{ab}}$ & $6(20.0 \%)^{\mathrm{a}}$ & $2(6.7 \%)^{\mathrm{a}}$ & 30 \\
\hline $\mathbf{1 0}^{-\mathbf{5}} \boldsymbol{\mu M}$ & $9(33.3 \%)^{\mathrm{b}}$ & $12(44.4 \%)^{\mathrm{a}}$ & $4(14.8 \%)^{\mathrm{a}}$ & $2(7.4 \%)^{\mathrm{a}}$ & 27 \\
\hline $\mathbf{1 0}^{-\mathbf{3}} \boldsymbol{\mu M}$ & $23(74.2 \%)^{\mathrm{a}}$ & $3(9.7 \%)^{\mathrm{b}}$ & $4(12.9 \%)^{\mathrm{a}}$ & $1(3.2 \%)^{\mathrm{a}}$ & 31 \\
\hline $\mathbf{1 0}^{-\mathbf{1}} \boldsymbol{\mu M}$ & $9(60.0 \%)^{\mathrm{ab}}$ & $4(26.7 \%)^{\mathrm{ab}}$ & $1(6.7 \%)^{\mathrm{a}}$ & $1(6.7 \%)^{\mathrm{a}}$ & 15 \\
\hline TOTAL & 56 & 26 & 15 & 6 & \\
\hline
\end{tabular}

During the morula stage there is activation of the fetal genome, which may be considered one of the most crucial moments. This activation takes place when the mother transcripts are substituted, starting from the fetal genome, and then begin to direct the initial development. This complex requires nuclear and cytoplasmatic modifications (Lima \& Sousa, 2009). According to Kanka (2003), changes in the structure of embryo chromatins at the initial stages exert a relevant role in genome activation but are not sufficient to activate transcription. In this context, other studies have observed that cytoplasmatic changes (mainly availability, content or activity of transcriptional factors) act together with chromatin changes for the success of transcription (Latham \& Schultz, 2001). According to the stop stage of the fetal development, melatonin at a lower concentration $\left(10^{-5} \mu \mathrm{M}\right)$ has a smaller percentage $(33.3 \%)$, thus presupposing that this quantity of melatonin aids in genome activation, decreasing the number of embryos that stagnate during the morula stage. This is unlike the $10^{-3} \mu \mathrm{M}$ concentration, which obtained an inverse reaction and provoked an increased stagnation of embryos during this development stage.

These results disagree with those of Tan et al. (1993), where $1 \mathrm{pM}$ and $100 \mu \mathrm{M}$ melatonin concentration increased bovine fetal development.

In vitro fetal development rates (\%) based on morphological quality are shown in Table 4. The proportion of Grade I was similar $(\mathrm{P}<0.05)$ in the control and $10^{-3} \mu \mathrm{M}$ groups; other groups did not present rates. For the proportion of Grade II, all treatments were similar $(\mathrm{P}<0.05)$, but the $10^{-5} \mu \mathrm{M}$ group did not present structures. 
Table 4. In vitro fetal development rates (\%) based on morphological quality (IETS, 2014) from COCs originated from post-mortem ovaries collected from slaughterhouses for embryo IVP, submitted or not to different melatonin treatments, evaluated on Days 5 and 7 after Day 0. Numbers followed by distinct lowercase letters differ by the $\chi 2$ test $(\mathrm{P}<0.05)$.

\begin{tabular}{llll|l}
\hline & GRADE I & GRADE II & GRADE III & TOTAL \\
\hline Control & $1(3.3 \%)^{\mathrm{a}}$ & $5(16.7 \%)^{\mathrm{a}}$ & $24(80.0 \%)^{\mathrm{b}}$ & 30 \\
$\mathbf{1 0}^{-\mathbf{1}} \boldsymbol{\mu M}$ & 0 & $1(6.7 \%)^{\mathrm{a}}$ & $14(93.3 \%)^{\mathrm{ab}}$ & 15 \\
$\mathbf{1 0}^{-\mathbf{3}} \boldsymbol{\mu M}$ & $1(3.2 \%)^{\mathrm{a}}$ & $4(12.9 \%)^{\mathrm{a}}$ & $26(83.9 \%)^{\mathrm{b}}$ & 31 \\
$\mathbf{1 0}^{-\mathbf{5}} \boldsymbol{\mu M}$ & 0 & 0 & $27(100 \%)^{\mathrm{a}}$ & 27 \\
\hline TOTAL & 2 & 10 & 91 & \\
\hline
\end{tabular}

Regarding the Grade III quality, the $10^{-5}$ $\mu \mathrm{M}$ and $10^{-1} \mu \mathrm{M}$ groups were similar, but the $10^{-5} \mu \mathrm{M}$ group was superior $(\mathrm{P}>0.05)$ to the control and $10^{-3} \mu \mathrm{M}$ groups. Control, $10^{-1} \mu \mathrm{M}$ and $10^{-3} \mu \mathrm{M}$ groups were similar $(\mathrm{P}<0.05)$.

According to Pocar et al. (2005), the quality of cumulus cells is considered to be a crucial factor that influences oocyte maturation and their subsequent development competence. However, even in the present study the lowest morphological quality (Grade III) showed a superior performance rate when submitted to $10^{-5} \mu \mathrm{M}$ melatonin treatment.

On the results of the first phase, melatonin supplementation of the in vitro maturation medium did not show evidence of improvements in oocyte maturation rates. In the second phase, melatonin supplementation at different concentrations during the in vitro production of embryos was able to improve the post fecundation phase in vitro. The $10^{-5} \mu \mathrm{M}$ group, in comparison to the other groups, presented higher cleavage, morula and blastocyst rates during the culture period. Thus, it is suggested that this treatment yields positive effects on the in vitro production of bovine embryos. However, higher melatonin concentrations, such as at $10^{-1} \mu \mathrm{M}$, resulted in negative effects on the presented rates when compared to the control group.

\section{REFERÊNCIAS BIBLIOGRÁFICAS}

ADONA, P. R.; PIRES, P. R.; QUETGLAS, M. D; SCHWARDZ, K. R.; LEAL, C. L. Nuclear maturation kinetics and in vitro embryo development of cattle oocytes prematured with butyrolactone I combined or not combined with roscovitine. Animal Science

Reproduction, v. 104, p. 389-397, 2008.

IETS. Statistics of Embryo Collection and Transfer in Domestic Farm Animals. Embryo Transfer Newsletter, v. 32, p. 14-26, 2014.

KANKA, J. Gene expression and chromatin structure in the pre-implantation embryo. Theriogenology, v.59, p.3-19, 2003.

LATHAM, K.E.; SCHULTZ, R. M. Embryonic genomic activation. Front Biosci, v.6, p.748-759, 2001.

LIMA, I. M. T.; SOUZA, A. L. Embryo development and survival during preimplantation period: focus in 
ruminants. Rev. Bras. Reprod. Anim., v.33, n.4, p.194-202, Oct./Dez. 2009.

LORD, T.; NIXON, B.; JONES, K.T.; AITKEN, R.J. Melatonin prevents postovulatory oocyte a ging in the mouse and extends the window for optimal fertilization in vitro. Biol Reprod, v.30, p.67-88, 2013.

MANJUNATHA, B.M.; DEVARAJ, M.; GUPTA, P.S.P.; RAVINDRA, J.P.; NANDI, S.. Effect of taurine and melatonin in the culture medium on buffalo in vitro embryo development. Reproduction in Domestic Animal 44: 12-16, 2009.

MERTON, J. S.; DE ROOS, A. P. W.; MULLAART, E.; DE RUIGH, L.; KAAL, L.; VOS, P. L. A. M.; DIELEMAN, S. J. Factors affecting oocyte quality and quantity in commercial application of embryo technologies in cattle breeding industry. Theriogenology, v. 59, p. 651674, 2003.

MOTLIK, J.; FULK, J. Factors affecting meiotic competence in pig oocytes.

Theriogenology 25 87-96, 1986.

PAPIS, K.; POLESZCZUK, O.; WENTAMUCHALSKA, E.; MODLINSKI, J. A. Melatonin effect on bovine embryo development in vitro in relation to oxygen concentration. Journal of Pineal

Research, v. 43, p. 321-236, 2007.

POCAR P., et al Apoptosis in bovine cumulus-oocyte complexes after exposure to polychlorinated biphenyl mixtures during in vitro maturation. Reproduction; v. 130 , p. $857-868,2005$.

RODRIGUEZ-OSÓRIO, N., KIM, I. J.; WANG, H., et al. Melatonin increases cleavage rate of porcine preimplantation embryos in vitro. Journal Pineal

Research. v. 43: p. 283-288, 2007.

SIRARD, M. A. Resumption of meiosis: mechanism involved in meiotic progression and its relation with developmental competence.

Theriogenology, v.55, p.1241-1254, 2001.

SIRARD, M.A.; RICHARD, F.; MAYES, $\mathrm{M}$. Controlling meiotic resumption in bovine oocytes: a review.

Theriogenology, v.49, p.483-497, 1998.

SIU AW, et al. Protective effects of melatonin in experimental free radicalrelated ocular diseases. Journal Pineal Research. v. 40, p. 101-109, 2006.

TAMURA, H.; TAKASAKI, A.;

TAKETANI, T.; TANABE, M.; KIZUKA, F.; LEE, L.; TAMURA, I.; MAEKAWA, R.; AASADA, H.; YAMAGATA, Y.; SUGINO, N. The role of melatonin as an antioxidant in the follicle. Journal of Ovarian Research, v. 5, p. 1757-2215, 2012.

TAN, D. X.; CHEN, L. D.; POEGGELER, B.; MANCHESTER, L. C. Melatonin: A potent, endogenous hydroxyl radical scavenger. Endocrinology, v. 1, p. 57-60, 1993.

THIBAULT, C.; SZOLLOSI, D.; GERARD, M. Mammalian oocyte maturation. Reproduction, Nutrition, Development 27 865-896, 1987.

THOMPSON J.G.; MITCHEL M.; KINO K. Embryo culture and long - term consequences. Reprod. Fert. And Dev., v. 19, p. 43-52, 2007

TSANTARLIOTOU, M. P.; ATTANASIO, L.; DE ROSA, A.; 
BOCCIA, L.; PELLERANO, G.;

GASPARRINI, B. The effect of melatonin on bovine in vitro embryo development.

Italian Journal Animals Sciencie. VOL. 6 (SUPPL. 1), 488-489, 2007.

VIANA, J. H. M. Statistics of embryo production and transfer in domestic farm animals: Is it a turning point? In 2017 more in vitro-produced than in vivoderived embryos were transferred worldwide. Embryo Transfer Newsl, v.36(4), p.8-25, 2018.

WETHERINGTON, J. Introduction to Biotechnology: A Georgia Teachers Resource Manual. 2010, 87p. 